\title{
Reflections on council
}

$\mathrm{O}$ $\mathrm{n}$ the last Sunday of August, I picked the first ripe tomato from my greenhouse and found myself smiling triumphantly. One of the North's great challenges had been overcome, and I cradled the warm, red trophy in my hand for a moment. Considering the greenhouse, the seedlings and my hourly rate, I would need to charge $\$ 500$ each for my tomatoes just to break even but not every farmer is in it for the money.

My three-year-old son helped excitedly with the rest of the harvesting beets, potatoes, basil, rosemary, parsley, carrots and snow peas - as we prepared a feast for some friends. The gooseberries we'd picked in the morning were being churned into sorbet, the house specialty. When our friends (a physician couple) arrived, their young boys headed for the raspberry patch and then picked more carrots - none of which made it to the table.

My colleagues, my husband and our children tucked into the meal, and we smiled to think that only a week ago, two of the physicians at the table had been in Saskatoon, Saskatchewan, for the Canadian Medical Association's 2009 General Council.

The Northwest Territories has a somewhat atypical physician population, which was well represented in the contingent to council. We tried to dress well for meetings, but our penchant for walking everywhere meant that we arrived on rainy days with our hair plastered to our heads. When the program warned that an evening event was NOT within walking distance (i.e. "please take the bus"), we happily trotted back to the hotel together while I quizzed one of our obstetricians about his experience as a foster parent to several children. Not unexpectedly, one of our delegates won the "Walk the Doc" challenge after logging 200 hours of exercise over the summer and our delegation won the provincial/territorial trophy, although we kept leaving it behind in conference rooms by accident.

I soon realized, in the course of debate, that the Northwest Territories is also a haven for idealism - not an ignorant bliss, but a desire to carefully articulate and live by the principles that



There are many ways to nurture a tomato, or an idea, says Yellowknife, Northwest Territories, physician Dr. Amy Hendricks.

first brought us into our profession (and in some cases, to Canada). A few times, one of us questioned an apparently indisputable resolution, usually out of concern that passing a token gesture without providing adequate funding for its implementation would be a somewhat meaningless gesture.

One of my colleagues brought forward perhaps the most controversial motion (censuring extra-billing, CMAJ 2009. DOI:10.1503/cmaj.109-3026), yet he spoke graciously and appealed to the finest motives in his fellow physicians. While listening to the debate, I was struck by its intensity, by the impassioned nature of everyone's beliefs and by how deftly and efficiently the speaker and deputy speaker handled the issue - and the entire agenda.

As a first-time delegate to council, I was also thankful for the patience and gracious feedback whenever I rose to address the assembly, particularly in light of the fact that some council delegates certainly knew much more about the political process and health care system than I did.

When I returned to my garden, my family and our beloved little hospital, I reflected that Canada's physicians need to recognize each other's strengths and experiences as we go through a process of health care transformation. General Council reminded me that the northern way is by no means the only way to practise medicine, yet northern physicians can at times bring frankness to important discussions. In the Arctic, we often witness struggles - and solutions - that may go unnoticed down south. Such as the nurse practitioner who helps run our ICU, or a patient snowmobiling three hours to see a specialist or the heroic effort to unite a tenecteplase dose with an elder in a bush camp.

Or, for that matter, the miracle of a truly ripe tomato above the $62 \mathrm{nd}$ parallel. Let us take nothing for granted. - Amy Hendricks MD, Yellowknife, NWT

DOI:10.1503/cmaj.109-3049

CMAJ invites contributions to "Dispatch from the medical front," in which physicians and other health care providers offer eyewitness glimpses of medical frontiers, whether defined by location or intervention. Submissions, which must run a maximum 700 words, should be forwarded to: wayne.kondro@cmaj.ca 